\title{
Penilaian Kinerja Berbasis Balanced Scorecards (BSC) untuk Melakukan Rancang Ulang Strategi Bersaing
}

\author{
Asdiana Dua Sumban ${ }^{1 *}$, Diana Zuhroh' ${ }^{2}$ Parawiyati $^{2}$ \\ ${ }^{1}$ Program Magister Akuntansi, Universitas Merdeka Malang, Malang, Indonesia \\ ${ }^{2}$ Program Studi Akuntansi, Fakultas Ekonomi dan Bisnis, Universitas Merdeka Malang, \\ Malang, Indonesia \\ *dianasumban@gmail.com
}

\begin{abstract}
The objectives of this study are to evaluate the performance of the Kusuma Agrowisata Hotel during the Covid-19 pandemic and to design the business strategy for the Hotel in new normal period. This research applies the quantitative and qualitative method. The data were obtained using questionnaires and interview and analyzed by applying descriptive statistics, using the Balanced Scorecard and SWOT analysis. The result shows that the hotel was less successful in improving revenue and efficiency. However the customers were satisfied and the hotel was able to achieve the company's strategy efficiency index and the staff satisfaction index. The SWOT analysis found out that there was $S$-O Strategy which could be done by keeping the room prices competitive, providing children's playground, keeping the good image, having a strategic location, maintaining the friendliness, maintaining the surrounding natural environment, keeping the guest demand fulfilled, reopening various tourist sites and setting strategies to eliminate customers boredom.
\end{abstract}

Keywords:, Balanced Scorecard, Hotel Performance, SWOT Analysis

\section{PENDAHULUAN}

Pandemi Covid-19 merupakan wabah yang membawa dampak besar baik dalam skala nasional maupun global, tidak terkecuali membawa dampak pada segala bidang perekonomian di Indonesia salah satunya pariwisata dan perhotelan. Selama pandemi, kegiatan perekonomian di Indonesia terganggu, salah satunya adalah pembatasan kunjungan baik dari luar negeri maupun dalam negeri, masyarakat dihimbau tidak berpergian dan tetap menjaga jarak.

Anjuran pemerintah untuk tetap tinggal dirumah, bekerja dari rumah dan sekolah dari rumah membawa perubahan besar bagi perekonomian di Indonesia. Menurunnya jumlah wisatawan baik dari luar maupun lokal berpengaruh juga terhadap kegiatan bisnis perhotelan.

Hasil pemaparan yang dilaporkan oleh Colliers International Indonesia, pada laporan kuartal II tahun 2020, okupansi hotel atau tingkat hunian di Surabaya, Jakarta hingga Bali terjadi penurunan drastis. Okupansi hotel di Jakarta pada Bulan April 2020 mengalami penurunan sampai $18 \%$, Bali mengalami penurunan yang lebih parah lagi, yaitu tidak sampai $5 \%$ dan Surabaya mengalami penurunan sekitar 10-15\% (detik finance, 2020). Di Kota Batu diketahui 80 hotel dan 1.000 villa mengalami penutupan selama pandemi (jpnn.com, 2020). Setelah beberapa bulan akhirnya pemerintah mengeluarkan kebijakan baru yaitu Pembatasan Sosial 
Berskala Besar (PSBB), kemudian dilanjutkan dengan menerapkan gaya hidup baru (new normal). Pada masa ini merupakan masa yang baik atau kabar baik bagi para pengusaha (pebisnis) yang terpuruk selama masa pandemi, tak terkecuali perhotelan. Hal ini terlihat terjadinya kenaikan okupansi (tingkat hunian) hotel, Jakarta naik menjadi $20 \%$, Bali menjadi 5\% dan Surabaya menjadi 16-17\% (detik finance, 2020), meskipun peningkatan ini dinilai belum menunjukkan sektor perhotelan benar-benar pulih.

Artikel terbitan McKinsey \& Company (perusahaan konsultan manajemen multinasional) mengungkapkan konsumen pada fase penerapan adaptasi kebiasaan baru cenderung mengutamakan nilai. Balanced Scorecard dapat digunakan untuk mengindikasikan peringatan awal secara menyeluruh bagi perusahaan tentang berhasil tidaknya dari sisi financial, proses bisnis, pelanggan, dan pembelajaran. Sehingga perusahaan memiliki kemampuan untuk melakukan respon perubahan dengan melakukan tindakan perbaikan, sehingga dapat lebih cepat dalam penanggulangan resiko (Diana Riyana, 2017). Benková et al (2020), menjelaskan definisi Balanced Scorecard sebagai konsep tentang bagaimana mentransfer visi dan strategi ke dalam tujuan metrik sehingga secara komprehensif mencakup tidak hanya bidang kinerja keuangan perusahaan, tetapi juga bidang nonkeuangan. Sumarsono (2014), menjelaskan strategi yang sesuai dengan perkembangan digital yang semakin pesat, banyak hotel mulai beradaptasi agar mampu bersaing secara kompetitif. Hotel harus diminta untuk menciptakan lingkungan yang adaptif dengan menciptakan digital environment yang bertujuan agar budaya kerja perusahaan mampu bertransformasi ke dunia digital dan menarik talenta handal untuk beradaptasi. Untuk itu inovasi yang diperlukan tidak hanya sekedar rutinitas biasa yang hanya berubah pada ukuran, bentuk, atau desain saja melainkan harus terjadi perubahan secara keseluruhan baik cara kerja, metode, maupun produk yang tidak memiliki relevansi para masa milenial ini.
Di Indonesia khususnya di Kota Batu diketahui salah satu hotel yang beroperasi adalah Hotel Kusuma Agrowisata. Kualitas hotel yang sudah termasuk bintang 4, menggambarkan kinerja hotel yang baik. Penelitian ini akan menganalisis bagaimana kinerja hotel dan strategi bersaing hotel Kusuma Agro Wisata dan juga memiliki tujuan untuk mengevaluasi kinerja Hotel Kusuma Agrowisata berbasis Balanced Scorecard selama pandemi Covid-19. Hasil evaluasi tersebut kemudian digunakan untuk merancang strategi bisnis Hotel Kusuma Agrowisata setelah pandemi Covid-19 (masa new normal) dengan analisis SWOT.

\section{Kinerja}

Kinerja merupakan sebuah hasil dari sebuah pekerjaan dan berkaitan dengan tujuan strategis organisasi, kepuasan terhadap pelanggan serta dapat berkontribusi terhadap ekonomi. Tujuan utama pengukuran kinerja adalah sebagai salah satu motivasi untuk karyawan dalam tercapainya sasaran organisasi serta dapat mematuhi standar perilaku yang telah ditentukan sebelumnya. Hal tersebut akan berimplikasi pada tindakan dan hasil yang diharapkan (Kurniasari, 2017). Salah satu faktor utama untuk unggul dalam persaingan global yaitu dengan meningkartkan kinerja perusahaan secara kontinu. Oleh karena itu perusahaan seyogyanya dapat melakukan pengukuran kinerja secara internal maupun eksternal sehingga dapat menumbuhkan dan mengembangkan perusahaan sehingga dapat bersaing (Widyastuti et al, 2018).

Tujuan dilakukannya penilaian kinerja adalah untuk memotivasi individu dalam ketercapaian tujuan organisasi serta menaati standar agar mendapatkan tindakan dan hasil yang diharapkan oleh organisasi. Metode Balanced Scorecard sering digunakan dalam mengukur kinerja. Kaplan dan Norton (2007) menjelaskan Balanced Scorecard dapat digunakan untuk mengukur kinerja perusahaan yang lebih inklusif, tidak hanya berkutat terhadap kinerja keuangan, namun dapat secara luas masuk pada kinerja non keuangan, seperti proses bisnis internal, 
perspektif pelanggan, dan juga pembelajaran dan pertumbuhan, seperti gambar berikut ini:

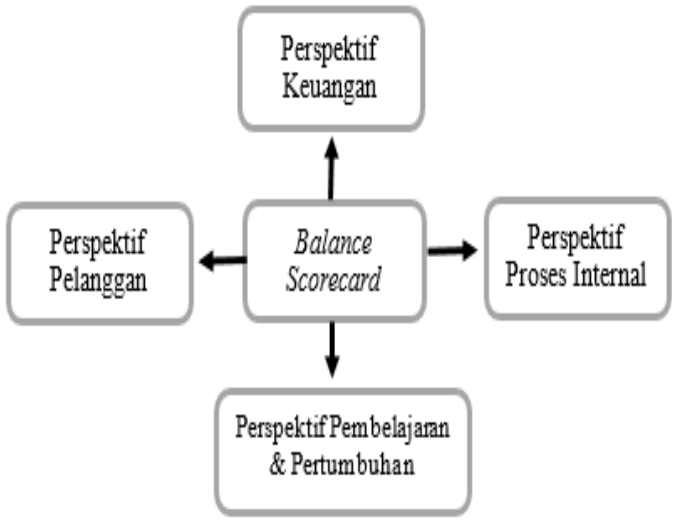

Gambar 1. Perspektif Balanced Scorecard

\section{Balanced Scorecard dapat} menjelaskan adanya keseimbangan antara berbagai ukuran eksternal dari pelanggan dan pemegang saham serta berbagai ukuran internal proses bisnis penting, inovasi serta pembelajaran dan pertumbuhan (Kaplan \& Norton, 2007). Dari berbagai ukuran tersebut dibagi kedalam empat perspektif dengan rincian sebagai berikut :

1) Persepktif Keuangan

$$
\text { Perspektif keuangan tetap }
$$

digunakan dalam Balanced Scorecard untuk menunujukkan rangkuman hasil kebijakan ekonomis yang telah dilakukan. Hal tersebut menjadikan perspektif keuangan menjadi sangat penting dalam pengukuran Balanced Scorecard. Ukuran kinerja finansial menginformasikan arahan strategi perusahaan, pengimplementasian, serta penerapannya dalam memberikan kontribusi pada meningkatnya laba yang diterima oleh perusahaan. Tujuan finansial lainnya dapat berwujud cepatnya pertumbuhan penjualan atau terciptanya arus kas (Kaplan and Norton, 2007). Pihak tata kelola perusahaan dapat melakukan penerapan pada beberapa rasio keuangan sebagai tolok ukur untuk menilai kemampuan perusahaan dalam memperoleh laba yang kaitannya dengan proses penjualan, modal sendiri, maupun total aktiva yaitu dengan menggunakan rasio keuangan. Rasio keuangan itu terdiri dari profitabilitas, return on assets, dan assets turn over.

2) Perspektif Pelanggan

Widiasri et al., (2017), Pelanggan merupakan aset perusahaan yang terbesar, karena tanpa pelanggan perusahaan tidak akan bisa berjalan dengan baik. Perspektif pelanggan merupakan salah satu rantai jasa tentang apa yang dilihat oleh pelanggan terhadap organisasi serta apa yang organisasi lihat pada pelanggan. Rantai jasa tersebut dapat dilihat menggunakan indikator tingkat kepuasan pelanggan melalui survey pelanggan sebagai cara untuk melihatnya. Dengan cara tersebut, sikap dan perilaku pelanggan dapat diketahui berdasarkan keluhan-keluahn dan kesan yang pelanggan sampaikan. Pelayanan perusahaan yang memuaskan akan membuat pelanggan lain untuk ikut berperan di perusahaan tersebut. Jika pelanggan merasa tidak puas, tidak menutup kemungkinan pelanggan akan mencari produsen lain yang sesuai dengan kebutuhan mereka. Untuk memuaskan pelanggan, usaha pelayanan yang baik tidak akan cukup, namun harus dapat mengerti apa yang dibutuhkan oleh pelanggan yang nantinya dipakai untuk usaha perusahaan dalam kaitanyya dengan kepuasan pelanggan.

3) Perspektif Bisnis Internal

Balanced Scorecard dalam proses bisnis internal memiliki tujuan menekankan berbagai proses utama yang dapat mendukung berhasilnya kiat-kiat atau strategi yang dilakukan oleh perusahaan, walaupun terdapat beberapa hal yang mungkin terdapat proses yang masih belum dilakukan. Balanced Scorecard dalam perspektif proses bisnis internal mencakup pada tujuan dan ukuran proses dalam menciptakan sebuah produk dan jasa yang baru untuk dapat terpenuhinya kebutuhan konsumen yang terus mengalami pertumbuhan. Oleh sebab itu, kemampuan mengelola proses jangka panjang dengan sukses dalam pengembangan produk atau pengembangan kapabilitas untuk dapat 
menjangkau kebutuhan konsumen yang baru adalah langkah yang lebih penting daripada kemampuan untuk melakukan kelola operasi pada saat ini secara konsisten, efisien, dan responsif (Rangkuti, 2006). Proses bisnis internal adalah berusaha mengetahui harapan konsumen maupun pelanggan serta pemegang saham ke dalam suatu proses bisnis. Dalam Balanced Scorecard, manajemen seyogyanya dapan menentukan proses bisnis secara lengkap mulai dari proses awal hingga akhir, sejak tahapan inovasi, tahapan operasional hingga kepada after sales. Scorecard dalam perspektif ini memungkinkan manajer untuk mengenali seberapa baik bisnis berjalan dan produk atau jasa yang telah dipasarkan sesuai dengan harapan atau keinginan pelanggan (Widiasri et al., 2017).

4) Perspektif Pembelajaran dan Pertumbuhan

Kaplan \& Norton (2007), mendefinisikan terdapat 3 sumber utama pembelajaran dan pertumbuhan perusahaan, yaitu bersumber dari manusia (Human), sistem, dan prosedur perusahaan. Balanced Scorecard pada Tujuan finansial, pelanggan, dan proses bisnis internal lazimnya menunjukkan ada tidaknya Gap antara kapabilitas SDM, sistem dan prosedur yang saat ini dijalankan dengan apa yang diinginkan untuk memperoleh kinerja yang penuh dengan terobosan. Kesenjangan ini dapat ditutup dengan cara perusahaan harus berinvestasi. Investasi ini dilakukan dengan cara memberikan pelatihan ulang kepada para pekerja, melakukan peningkatan teknologi dan sistem informasi, serta melakukan penyelarasan pada berbagai prosedur operasional dan kegiatan sehari-hari yang dilakukan oleh perusahaan. pegawai adalah individu yang bekerja pada suatu perusahaan, lembaga dengan menerima upah atau gaji yang diberikan kepada pegawai. Tujuan yang ditetapkan dalam perspektif pembelajaran dan pertumbuhan adalah tersedianya infrastruktur yang diharapkan dapat mencapai tujuan dalam tiga perspektif perusahaan (Widiasri et al., 2017).

\section{Analisis SWOT}

Permatasari (2015) dalam penelitiannya menjelaskan bahwa salah satu formulasi strategi ialah menggunakan analisis SWOT (Strengths, Weaknesses, Threats, Opporunities). Melasari dkk (2018) menjelaskan bahwa faktor faktor analisis SWOT antara lain :

1) Faktor IFAS (Internal Strategic Factors Analysis Summary/IFAS) Kekuatan/ Strenght, seperti: a) Fasiltas hotel yang lengkap dan memadai, b) Harga kamar hotel cukup kompetitif, c) Lokasi yang strategis, d) Kebersihan dan kenyamanan, e) Keramahan Karyawan, f) Area bermain untuk anak-anak

2) Faktor IFAS (Internal Strategic Factors Analysis Summary/IFAS) Kelemahan/ Weakness, seperti: a) Keefektifan dan kesinambungan promosi yang masih kurang, b) Belum tersedianya fasilitas Gym bagi para tamu, c) Perekrutan karyawan masih menggunakan sistem kekeluargaan, d) Keluhan dan saran dari para tamu yang belum terakomodir oleh pihak hotel.

3) Faktor EFAS (External Strategic Factors Analysis Summary/EFAS) Peluang/ Opportunities: a) Banyak pelanggan tetap, b) Adanya kerja sama yang dilakukan dengan baik dengan para supplier, c) Peningkatan daya tarik pengunjung dengan adanya kondisi alam yang memadai, d) Lama menginap wisatawan yang lebih tinggi dan memperoleh pendapatan perkapita yang tinggi, e) Pangsa pasar dari wisatawan domestik, f) Permintaan lain dari orang luar hotel terhadap produk-produk restoran.

4) Faktor EFAS (External Strategic Factors Analysis Summary/EFAS) Ancaman/T reath: a) Banyaknya hotel yang sejenis, b) Adanya perkembangan teknologi yang pesat, c) Semakin tingginya kuantitas dan kualitas pelayanan yang dimiliki hotel pesaing, d) Semakin banyak pesaing baru 
di dunia industri penginapan (home stay, guest house, hostel, losmen, dan sebagainya).

\section{Rancangan Strategi Pada Unit Bisnis}

Porter (1980), menjelaskan terdapat tiga strategi bisnis untuk memperoleh keunggulan bersaing antara lain :

1) Keunggulan Biaya Menyeluruh (cost leadership). Keunggulan biaya membutuhkan kepedulian khusus pada manajerial terhadap kendali biaya agar dapat tercapainya tujuan biaya yang rendah dari pesaing.

2) Diferensiasi (differentiation).

Diferensiasi ini memiliki strategi yaitu membedakan produk atau jasa yang ditawarkan sehingga dapat terciptanya sesuatu yang baru dan unik dalam industri tersebut.

3) Fokus (focus) adalah pemusatan (focus) pada kelompok pembeli, segmen lini produk, atau pasar geografis tertentu untuk tercapainya sasaran di keseluruhan industri sehingga mampu melayani target strategisnya yang sempit secara efektif.

Berdasarkan pemaparan literature review diatas, disusun kerangka konseptual dalam penelitian ini sebagai berikut:

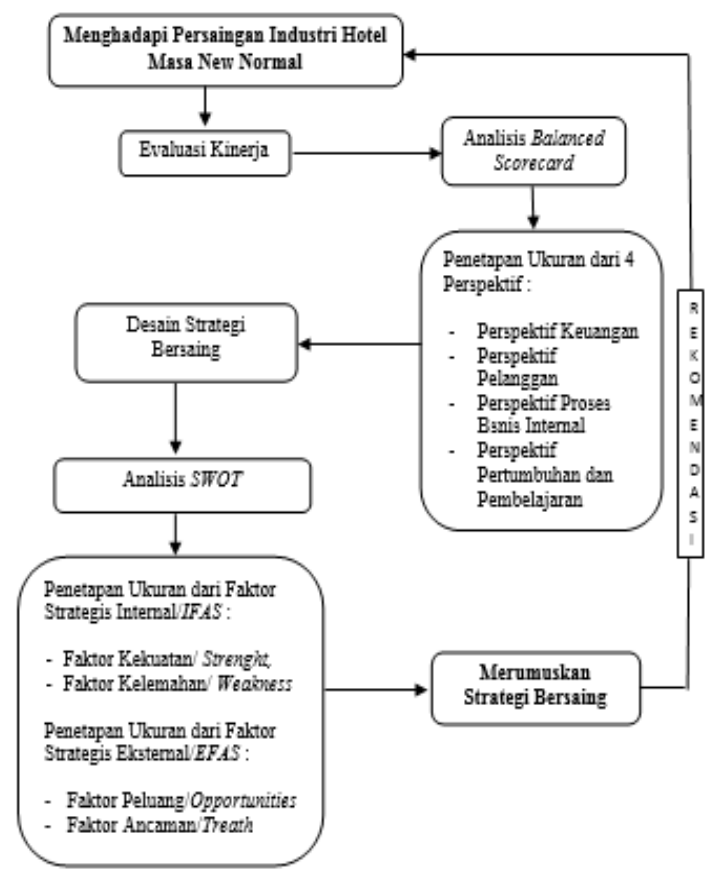

Gambar 2. Kerangka Konseptual Penelitian

\section{METODE}

Penelitian ini menggunakan pendekatan mixed methods desain Sequential Explanatory. Creswell (2013:5) (dalam (Chih-Pei \& Chang, 2017)) menjelaskan mixed methods adalah pendekatan penelitian yang mempergunakan dua pendekatan secara simultan yaitu antara kualitatif dan kuantitatif, dimana pada tahap pertama penelitian dilakukan dengan menggunakan metode kuantitatif dan pada tahap kedua dilakukan dengan metode kualitatif. Metode kuantitatif berperan untuk memperoleh data kuantitatif yang terukur yang dapat bersifat deskriptif, komparatif dan assosiatif dan metode kualitatif berperan untuk membuktikan, memperdalam, memperluas, memperlemah dan menggugurkan data kuantitatif yang telah diperoleh pada tahap awal.

Pelaksanaan penelitian untuk mengetahui gambaran dari kinerja yang dilakukan di Hotel Kusuma Agro Wisata Batu Malang pada tahun 2020 dengan menggunakan Balanced Scorecard dengan 4 perspektif dan Design Strategi Bersaing. Pengambilan sampel dalam penelitian ini adalah karyawan Hotel Kusuma Agro sebanyak 30 orang dan pelanggan/konsumen Hotel Kusuma Agro sebanyak 50 orang.

Teknik analisis data yang dipakai oleh peneliti dalam melakukan kegiatan riset dilakukan dengan beberapa langkah sehingga tujuan yang ditetapkan dapat tercapai. Adapun teknik analisis adalah sebagai berikut: 1) Tabulasi data, 2) Menghitung ratarata setiap jawaban yang ada dalam kuesioner, 3) Menganalisis kinerja dengan Balanced Scorecard meliputi: perspektif keuangan, perspektif pelanggan, perspektif proses bisnis internal serta perspektif pembelajaran dan pertumbuhan, 4) Melakukan analisis SWOT dengan menggunakan metode IFAS dan $E F A S$, 5) Membuat rancangan strategis perusahaan berdasarkan jawaban kuesioner. 
Tabel 1. Skor Alternatif Jawaban

\begin{tabular}{lcc}
\hline \multicolumn{1}{c}{ Alternatif } & \multicolumn{2}{c}{ Skor } \\
\cline { 2 - 3 } \multicolumn{1}{c}{ Jawaban } & Faktor IFAS & Faktor EFAS \\
\hline Sangat setuju & 4 & 1 \\
Setuju & 3 & 2 \\
Kurang setuju & 2 & 3 \\
Tidak setuju & 1 & 4 \\
\hline Sumber: Rangkuti 2006 &
\end{tabular}

Pemberian bobot penilaian tersebut digunakan untuk menjaring data yang diperoleh dari responden. Selanjutnya dianalisis menggunakan analisis SWOT. Analisis SWOT adalah membandingkan antara faktor eksternal (peluang dan ancaman) dengan faktor internal (kekuatan dan kelemahan). Faktor internal dimasukkan kedalam matrik yang disebut matrik faktor strategi Internal atau IFAS (Internal Strategic Factor Analisis Summary) dan Faktor eksternal dimasukkan ke dalam matrik yang disebut matrik faktor strategi eksternal EFAS (Eksternal Strategic Factor Analisis Summary).

\section{HASIL DAN PEMBAHASAN}

Hotel Kusuma Agrowisata merupakan salah satu anak perusahaan dari PT. Kusuma Satria Dinasasri Wisatajaya yang bergerak dalam bidang usaha agribisnis. Perusahaan ini mulai beroperasi pada tahun 1989 dengan nama PT. Panderman Indera Jaya. Tanggal 21 Mei 1990 PT. Panderman Indera Jaya berganti nama menjadi PT. Kusuma Satria Dinasasri Wisatajaya. Kusuma Agrowisata adalah satu dari sekian bentuk objek wisata yang memiliki basis pertanian. Berlokasi di daerah Kota Wisata Batu menjadikan wisata ini memiliki hawa yang sejuk dengan pemandangan alam yang indah. Kusuma Agrowisata dikelilingi oleh beberapa gunung antara lain Gunung Panderman, Arjuno, Welirang, Anjasmoro, dan Gunung Kawi. Kota Batu tersohor sebagai kota wisata karena karakteristik tersebut. Karena kondisi tersebut, Kusuma Agrowisata sangat cocok dijadikan tempat untuk melakukan pertanian holtikultura.
Selama masa pandemi Covid-19 Hotel Kusuma Agrowisata, telah menerapkan protokol kesehatan untuk mencegah penularan Covid-19 baik kepada pelanggan maupun bagi karyawan. Beberapa usaha yang dilakukan oleh manajemen hotel untuk mencegah penularan Covid-19 adalah: membuat standar operasional prosedur (SOP), menyediakan dan memasang himbauan tertulis serta menerapkan protokol kesehatan dasar bagi karyawan, tamu, dan pihak lain yang beraktivitas di hotel seperti menggunakan masker, menjaga jarak, dan mencuci tangan. Panduan khusus meliputi 3 alur pelayanan hotel mulai dari pintu masuk hingga ruang karyawan, yaitu panduan bagi pengusaha dan pengelola terhadap fasilitas yang harus disediakan, panduan tamu, serta panduan bagi karyawan.

Berdasarkan dengan data keuangan dan non keuangan yang diperoleh dengan mempergunakan metode kuesioner dan dokumentasi maka dapat dihitung kinerja Hotel Kusuma Agrowisata pada empat perspektif sesuai dengan konsepsi Balanced Scorecard yang sudah dirumuskan di bab terdahulu yakni:

\section{Analisis Kinerja Balanced Scorecard: Perspektif Keuangan}

Perspektif keuangan diukur dengan profitabilitas yaitu margin laba kotor, margin laba operasi, dan return of asset (ROA).

Tabel 2. Perhitungan Rasio Profitabilitas

\begin{tabular}{|c|c|c|c|c|}
\hline No & Variabel & Rumus & $\begin{array}{l}\text { Tahun } \\
2019\end{array}$ & $\begin{array}{l}\text { Tahun } \\
2020\end{array}$ \\
\hline 1 & $\begin{array}{l}\text { Margin } \\
\text { Laba }\end{array}$ & $\begin{array}{l}\text { Laba Kotor } \mathrm{x} \\
100 \%\end{array}$ & 9,81 & $-43,97$ \\
\hline & Kotor & $\begin{array}{l}\overline{\text { Total }} \\
\text { Penjualan }\end{array}$ & & \\
\hline 2 & $\begin{array}{l}\text { Margin } \\
\text { Laba } \\
\text { Operasi }\end{array}$ & $\begin{array}{l}\text { Laba Operasi } \underline{x} \\
\frac{100 \%}{\text { Total }}\end{array}$ & 65,91 & $-134,4$ \\
\hline 3 & ROA & $\begin{array}{l}\text { Penjualan } \\
\text { EAT x 100\% } \\
\text { Total Aktiva }\end{array}$ & 3,88 & $-5,76$ \\
\hline
\end{tabular}

Sumber : Data sekunder diolah, 2021

Berdasarkan hasil perhitungan kinerja perspektif keuangan (margin laba kotor, margin Laba Operasi dan perhitungan ROA) 
hotel Kusuma Agrowisata pada tahun 2019 memperlihatkan kinerja yang sangat bagus, akan tetapi pada tahun 2020 mengalami penurunan pendapatan yang cukup signifikan. Hal ini berdampak pada posisi keuangan perusahaan yang menurun diakibatkan terjadinya pandemi Covid-19.

\section{Analisis Kinerja Balanced Scorecard: Perspektif Pelanggan}

Sasaran perspektif ini adalah mengukur retensi pelanggan, akuisisi Pelanggan, image hotel dan kepuasan masyarakat terhadap layanan hotel selama masa pandemi. Pengukuran kepuasan pelanggan dilakukan dengan menggunakan kuesioner. Jumlah kuesioner yang dibagikan kepada pelanggan sebanyak 50 dan yang kembali adalah 50 dan semuanya memenuhi syarat untuk diolah. Proses penyebarannya dilakukan dengan menyebarkan kuesioner kepada siapa saja yang menjadi pelanggan Hotel Kusuma Agrowisata. Adapun karakteristik pelanggan yang berpartisipasi sebagai responden adalah sebagai berikut:

Tabel 3. Karakteristik pelanggan

\begin{tabular}{lcc}
\hline Keterangan & F & $\%$ \\
\hline Jenis Kelamin & & \\
$\quad$ Pria & 21 & $42 \%$ \\
$\quad$ Wanita & 29 & $58 \%$ \\
Usia & & \\
$\quad 17-24$ tahun & 11 & $22 \%$ \\
$25-34$ tahun & 11 & $22 \%$ \\
$35-49$ tahun & 23 & $46 \%$ \\
$50-65$ tahun & 5 & $10 \%$ \\
Pekerjaan & & \\
Pelajar/Mahasiswa & 8 & $16 \%$ \\
Pegawai Negeri & 9 & $18 \%$ \\
Pegawai Swasta & 20 & $40 \%$ \\
Lainnya & 9 & $18 \%$ \\
Tidak bekerja & 4 & $8 \%$ \\
$\quad$ Jumlah & 50 & $100 \%$ \\
\hline
\end{tabular}

Sumber: Data primer diolah, 2021

Dari Tabel 3 di atas, dapat diketahui bahwa dari 50 pelanggan Hotel Kusuma Agrowisata, sebanyak 21 pelanggan $(42 \%)$ berjenis kelamin pria dan sebanyak 29 pelanggan $(58 \%)$ berjenis kelamin wanita. Sebanyak 11 pelanggan (22\%) berumur antara 17-24 tahun, sebanyak 11 pelanggan (22\%) berumur 25-34 tahun, sebanyak 23 pelanggan (46\%) berumur 35- 49 tahun dan sebanyak 5 pelanggan $(10 \%)$ berumur antara 50-65 tahun. Dari 50 pelanggan hotel Kusuma Agrowisata, sebanyak 8 pelanggan (16\%) adalah pelajar/mahasiswa, sebanyak 9 pelanggan (18\%) adalah pegawai negeri, sebanyak 20 pelanggan (40\%) adalah pegawai swasta, sebanyak 9 pelanggan $(18 \%)$ bekerja lainnya dan sebanyak 4 pelanggan (8\%) tidak bekerja.

Dari hasil tabulasi data kuesioner maka dapat di interpretasikan beberapa hal, sebagai berikut:

1) Retensi Pelanggan Selama Masa Pandemi Dari 50 kuesioner yang disebarkan kepada pelanggan, jawaban yang diberikan responden dapat dilihat pada tabel di bawah ini:

Tabel 4. Distribusi Frekuensi Jawaban Responden Kuesioner Retensi Pelanggan

\begin{tabular}{|c|c|c|c|c|c|c|c|c|}
\hline \multirow{2}{*}{ Pertanyaan } & \multicolumn{2}{|c|}{1} & \multicolumn{2}{|c|}{2} & \multicolumn{2}{|c|}{3} & \multicolumn{2}{|c|}{4} \\
\hline & $\mathrm{f}$ & $\%$ & $f$ & $\%$ & $\mathrm{f}$ & $\%$ & $\bar{f}$ & $\%$ \\
\hline $\begin{array}{l}\text { Berapa kali } \\
\text { konsumen } \\
\text { datang dan } \\
\text { melakukan } \\
\text { pemesanan }\end{array}$ & 6 & 12 & 21 & 42 & 16 & 32 & 7 & 14 \\
\hline
\end{tabular}

Hasil sebaran kuesioner retensi pelanggan selama masa pandemi adalah sebagian besar merupakan pelanggan yang telah berkunjung kedua kali yaitu sebanyak 21 orang (42\%), sehingga dapat disimpulkan sebagian besar pelanggan Agrowisata Hotel merupakan pelanggan lama. Hal ini menunjukkan bahwa retensi pelanggan dapat dikatakan baik karena hotel Kusuma Agrowisata mampu mempertahankan pelanggannya.

2) Akuisisi Pelanggan

Akuisisi Pelanggan (Custometer Acquisition) sebagai tolok ukur sebanyak apa perusahaan mampu mendapatkan pelanggan baru atau memenangkan bisnis baru baik pada pengukuran akuisisi pelanggan. Dari 50 pelanggan, diketahui sebanyak 6 orang merupakan pelanggan 
baru, dan 44 orang merupakan pelanggan lama, maka perhitungan akuisisi pelanggan adalah sebagai berikut:

$$
\begin{aligned}
& \text { Akuisisi Pelanggan }=\frac{\text { Jumlah Pelanggan baru }}{\text { Jumlah Pelanggan }} \times 100 \% \\
& =\frac{6}{50} \times 100=12 \%
\end{aligned}
$$

Berdasarkan perhitungan di atas maka diketahui bahwa hotel Kusuma Agrowisata mampu meningkatkan jumlah pelanggan sebanyak $12 \%$, maka akuisisi pelanggan Hotel dapat dikategorikan baik karena mampu menarik pelanggan baru.

3) Kepuasan Masyarakat/Pelanggan

Untuk mengukur kepuasan pelanggan terhadap layanan hotel ada 5 pertanyaan yang diajukan kepada responden. Dari hasil kuesioner yang disebarkan, telah melalui proses uji validitas dan reliabilitas menggunakan SPSS versi 20.0 dengan hasil seluruh item pertanyaan telah valid dan reliabel.

Hasil jawaban responden dapat dilihat pada tabel berikut:

Tabel 5. Distribusi Frekuensi Jawaban Responden

\begin{tabular}{|c|c|c|c|c|c|c|c|c|c|c|c|}
\hline \multirow{2}{*}{ Pertanyaan } & \multicolumn{2}{|c|}{ STP } & \multicolumn{2}{|c|}{ TP } & \multicolumn{2}{|c|}{$\mathrm{N}$} & \multicolumn{2}{|c|}{$\mathrm{P}$} & \multicolumn{2}{|c|}{ SP } & \multirow{2}{*}{ Mean } \\
\hline & $\mathrm{f}$ & $\%$ & f & $\%$ & $\mathrm{f}$ & $\%$ & $\mathrm{f}$ & $\%$ & f & $\%$ & \\
\hline $\begin{array}{l}\text { Pelayanan } \\
\text { yang } \\
\text { diberikan }\end{array}$ & 0 & 0 & 0 & 0 & 5 & 10 & 30 & 60 & 15 & 30 & 4,2 \\
\hline $\begin{array}{l}\text { Kemudahan } \\
\text { akses }\end{array}$ & 0 & 0 & 1 & 2 & 2 & 4 & 26 & 52 & 21 & 42 & 4,34 \\
\hline $\begin{array}{l}\text { Penyedia } \\
\text { fasilitas }\end{array}$ & 0 & 0 & 0 & 0 & 2 & 4 & 31 & 62 & 17 & 34 & 4,3 \\
\hline $\begin{array}{l}\text { Penyedia } \\
\text { layanan }\end{array}$ & 0 & 0 & 0 & 0 & 12 & 24 & 21 & 42 & 17 & 34 & 4,1 \\
\hline Respon hotel & 0 & 0 & 0 & 0 & 19 & 38 & 21 & 42 & 10 & 20 & 3,82 \\
\hline
\end{tabular}
Kepuasan Pelanggan

Rata-rata Skor epuasan Pelanggan

Sumber: Data primer diolah, 2021

Tabel 5 menunjukkan skor rata-rata 4,15. Ada 3 butir pertanyaan memiliki skor diatas rata-rata yaitu 4,34 mengenai kemudahan mengakses jasa yang ditawarkan oleh hotel, kepuasan pelanggan atas penyediaan fasilitas hotel secara umum dengan skor rata-rata 4,30 dan pelayanan yang diberikan oleh hotel kepada pelanggan dengan skor rata-rata 4,20. Ini membuktikan bahwa pelanggan merasa puas ketika menginap dihotel Kusuma Agrowisata.
4) Image Hotel

Dari 50 kuesioner yang disebarkan kepada pelanggan, jawaban yang diberikan responden dapat dilihat pada tabel di bawah ini:

Tabel 6. Distribusi Frekuensi Jawaban Responden Kuesioner Image Hotel

\begin{tabular}{lllllllllll}
\hline \multirow{2}{*}{ Pertanyaan } & \multicolumn{1}{c}{ STB } & \multicolumn{1}{c}{ KB } & \multicolumn{1}{c}{ CB } & \multicolumn{2}{c}{ B } & \multicolumn{2}{c}{ SB } \\
\cline { 2 - 10 } & f & $\%$ & f & $\%$ & f & $\%$ & f & $\%$ & f & $\%$ \\
\hline $\begin{array}{l}\text { Bagaimana persepsi } \\
\text { anda terhadap citra } \\
\text { (image) hotel }\end{array}$ & & & & 13 & 26 & 26 & 52 & 11 & 22 \\
\hline Sumber: Data primer diolah, & 2021 & & & & & & & & &
\end{tabular}

Hasil sebaran kuesioner tentang image hotel selama masa pandemi diperoleh: kategori cukup baik sebanyak 13 orang (26\%), baik sebanyak 26 orang (52\%), dan sangat baik sebanyak 11 orang ( $22 \%$ ), sehingga dapat disimpulkan bahwa image Hotel Kusuma Agrowisata dapat dikatakan baik karena hotel mampu memberikan kesan yang positif kepada para pelanggannya.

\section{Analisis Kinerja Balanced Scorecard: Perspektif Proses Bisnis Internal}

Sasaran perspektif ini adalah meningkatkan efisiensi strategi perusahaan, pengembangan produk dan kapabilitas perusahaan. Pengukuran efisiensi strategi perusahaan dilakukan dengan menggunakan kuesioner. Data dari kuesioner tersebut bersifat kualitatif dan kemudian diubah menjadi data yang bersifat kuantitatif. Adapun karakteristik karyawan yang berpartisipasi sebagai responden adalah sebagai berikut:

Tabel 7. Karakteristik Responden

\begin{tabular}{lcc}
\hline \multicolumn{1}{c}{ Keterangan } & F & $\%$ \\
\hline Jenis Kelamin & & \\
$\quad$ Pria & 16 & 53,3 \\
$\quad$ Wanita & 14 & 46,7 \\
Usia & & \\
$\quad 17-24$ tahun & 8 & 26,7 \\
$25-34$ tahun & 12 & 40 \\
$\quad 35-49$ tahun & 10 & 33,3 \\
Pendidikan & & \\
$\quad$ SMA & 15 & 50 \\
Diploma & 6 & 20 \\
$\quad$ Sarjana Jumlah & 9 & 30 \\
$\quad$ & 30 & 100 \\
\hline
\end{tabular}

Sumber: Data primer diolah, 2021 
Berdasarkan tabel di atas dapat diketahui bahwa dari 30 karyawan Hotel Kusuma Agrowisata yang berpartisipasi sebagai responden, 16 karyawan $(53,3 \%)$ berjenis kelamin pria dan 14 karyawan $(46,7 \%)$ berjenis kelamin wanita. Dari 30 karyawan hotel Kusuma yang kuesioner. Kuesioner telah melalui proses uji validitas dan reliabilitas, adapun hasil uji validitas seluruh item kuesioner memperoleh nilai signifikansi $<0,05$ nilai Cronbach's Alpha sebesar 0,722 yang berarti > 0,6 maka item kuesioner dinyatakan valid dan reliabel.

Setelah Kuesioner dinyatakan valid dan reliabel maka hasil dari jawaban resberpartisipasi, sebanyak 8 karyawan (26,7\%) berumur 17-24 tahun, sebanyak 12 karyawan (40\%) berumur 25-34 tahun, dan sebanyak 10 karyawan $(33,3 \%)$ berumur 35 49 tahun. Sebanyak 15 karyawan (50\%) berpendidikan SMA, sebanyak 6 karyawan (20\%) berpendidikan Diploma, dan sebanyak 9 karyawan $(30 \%)$ berpendidikan sarjana.

Kuesioner yang disebar sebelumnya telah melalui proses uji validitas dan reliabilitas, adapun hasil uji validitas dihasilkan nilai signifikansi $<0,05$ dan nilai reliabilitas sebesar 0,615. Maka item kuesioner dinyatakan valid dan reliabel. Setelah Kuesioner dinyatakan valid dan reliabel maka kuesioner disebarkan kepada pelanggan, adapun hasil dari jawaban responden dapat dilihat pada Tabel 8 berikut:

Tabel 8. Distribusi Frekuensi Jawaban Kuesioner Proses Bisnis Internal

\begin{tabular}{|c|c|c|c|c|c|c|c|c|c|c|c|}
\hline \multirow{2}{*}{ Pertanyaan } & \multicolumn{2}{|c|}{ STS } & \multicolumn{2}{|c|}{$\mathrm{TS}$} & \multicolumn{2}{|c|}{$\mathrm{N}$} & \multicolumn{2}{|c|}{$\mathrm{S}$} & \multicolumn{2}{|c|}{ SS } & \multirow[b]{2}{*}{ Mean } \\
\hline & $\mathrm{f}$ & $\%$ & $\mathrm{f}$ & $\%$ & $f$ & $\%$ & $f$ & $\%$ & $F$ & $\%$ & \\
\hline Pelayanan & 0 & 0 & 0 & 0 & 19 & 63,3 & 11 & 36,7 & 0 & 0 & 3,36 \\
\hline $\begin{array}{l}\text { Kemudahan } \\
\text { Akses }\end{array}$ & 0 & 0 & 0 & 0 & 6 & 20 & 14 & 46,7 & 10 & 33,3 & 4,33 \\
\hline Fasilitas & 0 & 0 & 0 & 0 & 23 & 76,7 & 5 & 16,7 & 2 & 6,7 & 3,3 \\
\hline Layanan & 0 & 0 & 0 & 0 & 3 & 10 & 16 & 53,3 & 11 & 36,7 & 4,26 \\
\hline Respon hotel & 0 & 0 & 0 & 0 & 1 & 3,3 & 11 & 36,7 & 18 & 60 & 4,56 \\
\hline & & & & r R & 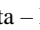 & Rata & & & & & 3,92 \\
\hline
\end{tabular}

Sumber: Data primer diolah, 2021

Dari Tabel 8 di atas, terlihat skor ratarata menunjukkan angka 3,92. Hal ini menunjukkan tingkat efisiensi strategi sangat efisien terutama respon hotel terhadap keluhan dan ketidak puasan tamu diatas skor rata-rata $(4,56)$, penyediaan layanan untuk kemudahan reservasi $(4,26)$ dan kemudahan akses mengenai jasa yang ditawarkan oleh hotel diatas rata-rata $(4,13)$.

\section{Analisis Kinerja Balanced Scorecard: Perspektif Pertumbuhan dan Pembelajaran}

1) Produktivitas Karyawan

Aspek ini bertujuan untuk mengetahui produktivitas karyawan selama satu periode, yaitu dengan menghitung perbandingan antara laba operasi dengan total keseluruhan karyawan.

Tabel 9. Produktifitas Karyawan

\begin{tabular}{ccrr}
\hline Tahun & $\begin{array}{c}\text { Jumlah } \\
\text { Karyawan }\end{array}$ & \multicolumn{1}{c}{ Laba Operasi } & Produktivitas \\
\hline 2019 & 161 & 27.001 .869 .622 & 167.713 .476 \\
2020 & 156 & 7.314 .595 .138 & 46.888 .430 \\
\hline
\end{tabular}

Sumber: Data primer diolah, 2021

Dari tabel di atas dapat diketahui bahwa pada tahun 2019 dengan jumlah 161 karyawan diperoleh pendapatan sebesar Rp167.713.476,00 sedangkan pada tahun 2020 dengan jumlah 156 karyawan diperoleh pendapatan sebesar Rp46.888.430,00

2) Perputaran Karyawan

Aspek perputaran karyawan bertujuan untuk mengetahui perbandingan antara karyawan yang keluar terhadap total karyawan. Idealnya dalam satu tahun, ratarata pegawai keluar kurang dari $3 \%$.

Tabel 10. Perputaran Karyawan

\begin{tabular}{cccc}
\hline Tahun & $\begin{array}{c}\text { Jumlah } \\
\text { Karyawan }\end{array}$ & Keluar & $\%$ \\
\hline 2019 & 161 & 5 & 3,1 \\
2020 & 156 & 80 & 51,3 \\
\hline
\end{tabular}

Sumber: Data primer diolah, 2021

Berdasarkan Tabel 10 di atas dapat diketahui bahwa pada tahun 2019 dengan jumlah 161 karyawan terdapat 5 karyawan $(3,1 \%)$ yang keluar. Sedangkan pada tahun 2020 dari jumlah 156 karyawan terdapat 80 $(51,3 \%)$ karyawan yang keluar.

3) Kepuasan Karyawan

Sasaran perspektif ini adalah meningkatkan kepuasan, akuisisi dan loyalitas dari karyawan perusahaan. Pengukuran kepuasan karyawan dilakukan 
dengan menggunakan responden dapat dilihat pada Tabel 11 berikut :

Tabel 11. Distribusi Frekuensi Jawaban Kepuasan Karyawan

\begin{tabular}{|c|c|c|c|c|c|c|c|c|c|c|c|}
\hline \multirow{2}{*}{ Pertanyaan } & \multicolumn{3}{|c|}{ STP } & \multicolumn{2}{|l|}{ TP } & \multicolumn{2}{|l|}{$\mathrm{N}$} & \multicolumn{2}{|l|}{$\mathrm{P}$} & SP & \multirow{2}{*}{ - Mean } \\
\hline & $\mathrm{f}$ & $\%$ & $\mathrm{f}$ & $\%$ & $\mathrm{f}$ & $\%$ & $\mathrm{~F}$ & $\%$ & f & $\%$ & \\
\hline $\begin{array}{l}\text { Fasilitas } \\
\text { teknologi } \\
\text { komunikasi }\end{array}$ & 0 & 0 & 0 & 0 & 13 & 43,3 & 15 & 50 & 2 & 6,7 & 3,63 \\
\hline $\begin{array}{l}\text { Gaji yang } \\
\text { diterima }\end{array}$ & 0 & 0 & 0 & 0 & 13 & 43,3 & 13 & 43,3 & 4 & 13,3 & 3,70 \\
\hline $\begin{array}{l}\text { Perilaku } \\
\text { atasan }\end{array}$ & 0 & 0 & 0 & 0 & 11 & 36,7 & 15 & 50 & 4 & 13,3 & 3,80 \\
\hline $\begin{array}{l}\text { Perilaku } \\
\text { rekan kerja }\end{array}$ & 0 & 0 & 1 & 3,3 & 11 & 36,7 & 13 & 43,3 & 5 & 16,7 & 3,73 \\
\hline $\begin{array}{l}\text { Adanya } \\
\text { promosi }\end{array}$ & 0 & 0 & 1 & 3,3 & 13 & 43,3 & 12 & 40 & 4 & 13,3 & 3,63 \\
\hline $\begin{array}{l}\text { Fasilitas } \\
\text { hotel }\end{array}$ & 0 & 0 & 0 & 0 & 19 & 63,3 & 9 & 30 & 5 & 6,7 & 3,43 \\
\hline $\begin{array}{l}\text { Program } \\
\text { konpensasi }\end{array}$ & 0 & 0 & 0 & 0 & 21 & 70 & 7 & 23,3 & 2 & 6,7 & 3,43 \\
\hline kemudahan & 0 & 0 & 0 & 0 & 12 & 40 & 16 & 53,3 & 2 & 6,7 & 3,70 \\
\hline $\begin{array}{l}\text { Pelatihan } \\
\text { dan } \\
\text { pendidikan }\end{array}$ & 0 & 0 & 0 & 0 & 17 & 56,7 & 10 & 33,3 & 3 & 10 & 3,53 \\
\hline $\begin{array}{l}\text { Fasilitas } \\
\text { yang }\end{array}$ & 0 & 0 & 2 & 6,7 & 15 & 50 & 10 & 33,3 & 3 & 10 & 3,50 \\
\hline & & & Tot & al sk & 110 & $-\mathrm{ra}$ & & & & & 3,59 \\
\hline
\end{tabular}

Sumber: Data primer diolah, 2021

Dari Tabel 11 di atas, skor rata-rata menunjukkan angka 3,59 dan pada butir 3 (perilaku atasan), butir 4 (perilaku rekan kerja), butir 8 (kemudahan akses informasi), butir 2 (gaji yang diterima), butir 1 (fasilitas teknologi komunikasi) dan butir 5 (promosi di tempat kerja) dari pertanyaan memiliki skor diatas rata-rata, ini menunjukkan bahwa sebagian besar karyawan sangat puas bekerja pada hotel Kusuma Agrowisata.

\section{Hasil Analisa SWOT dan AHP}

Perhitungan Analisis SWOT meliputi: 1) Ringkasan dari kuesioner berisi rata-rata, median atau kuartil dari jawaban para ahli yang disesuaikan dengan kondisi dan teori untuk faktor eksternal. Adapun hasil ringkasan data kuesioner dapat dilihat pada lampiran 1; 2) Matriks Evaluasi Faktor Eksternal dan Internal IFAS (Internal Factors Analysis Strategic)

Identifikasi faktor-faktor yang merupakan kekuatan dan kelemahan meliputi: 1) Dilakukan skala pembobotan pada masingmasing faktor dengan skala 0 yang berarti tidak penting hingga skala 1 yang berarti sangat penting. Jumlah keseluruhan bobot pada satu faktor adalah 1; 2) Pengaruh terhadap masalah yang muncul kemudian diberikan rating untuk masing-asming faktor dengan range 1 (poor) hingga 4 (outstanding); 3) Kekuatan diberikan nilai rating. Kekuatan paling besar diberikan rating paling tinggi, begitu pula sebaliknya; 4) Menghitung skor terbobot setiap faktor dengan mengalikan bobot dengan rating; 5) Interpretasi jumlah skor terbobot. Apabila jumlah skor lebih dari atau sama dengan 2,5 memiliki arti internal sistem dapat mengatasi situasi yang terjadi.

Adapun hasil IFAS (Internal Factors Analysis Strategic) dapat dilihat pada Tabel 12 di bawah ini:

Tabel 12. Matriks Evaluasi Faktor IFAS

\begin{tabular}{|c|c|c|c|}
\hline $\begin{array}{l}\text { Faktor-faktor } \\
\text { internal kunci }\end{array}$ & Rating & Bobot & $\begin{array}{l}\text { Nilai } \\
\text { terbobot }\end{array}$ \\
\hline Kekuatan: & & & \\
\hline $\begin{array}{l}\text { Harga kamar yang } \\
\text { kompetitif }\end{array}$ & 2,7 & 0,10 & 0,26 \\
\hline $\begin{array}{l}\text { Adanya tempat } \\
\text { bermain untuk anak- } \\
\text { anak }\end{array}$ & 2,7 & 0,10 & 0,26 \\
\hline $\begin{array}{l}\text { Hotel memiliki citra } \\
\text { yang baik }\end{array}$ & 2,9 & 0,10 & 0,30 \\
\hline $\begin{array}{l}\text { Memiliki lokasi yang } \\
\text { strategis }\end{array}$ & 3,0 & 0,11 & 0,32 \\
\hline $\begin{array}{l}\text { Keramahan dan } \\
\text { kesopanan pelayan }\end{array}$ & 3,6 & 0,13 & 0,46 \\
\hline Jumlah Kekuatan & & & 1,58 \\
\hline Kelemahan : & & & \\
\hline $\begin{array}{l}\text { Promosi Hotel yang } \\
\text { belum efektif }\end{array}$ & 2,4 & 0,08 & 0,20 \\
\hline $\begin{array}{l}\text { Jumlah kamar yang } \\
\text { sedikit }\end{array}$ & 2,4 & 0,08 & 0,20 \\
\hline $\begin{array}{l}\text { Kondisi hotel, } \\
\text { terkadang ada } \\
\text { keluhan }\end{array}$ & 2,9 & 0,10 & 0,30 \\
\hline $\begin{array}{l}\text { Tidak ada paket } \\
\text { diskon Hotel }\end{array}$ & 3,4 & 0,12 & 0,41 \\
\hline $\begin{array}{l}\text { Kurang menerapkan } \\
\text { kemajuan teknologi }\end{array}$ & 2,4 & 0,08 & 0,20 \\
\hline Jumlah Kelemahan & & & 1.32 \\
\hline \multicolumn{3}{|l|}{ Jumlah } & 2,89 \\
\hline
\end{tabular}

Sumber: Data primer diolah, 2021

Selanjutnya Metode AHP dilakukan untuk mengurangi tingkat subjektivitas pada nilai bobot sehingga dapat menghasilkan kesimpulan yang lebih objektif. Tingkat 
objektivitas nilai bobot dapat dilihat dari nilai rasio inkonsistensinya.

Identifikasi faktor-faktor yang merupakan peluang dan ancaman meliputi tahapan: 1) Dilakukan skala pembobotan pada masing-masing faktor dengan skala 0 yang berarti tidak penting hingga skala 1 yang mempunyai arti sangat penting. Jumlah keseluruhan bobot pada satu faktor adalah 1; 2) Pengaruh terhadap masalah yang muncul kemudian diberikan rating untuk masingasming faktor dengan range 1 (poor) hingga 4 (outstanding); 3) Peluang diberikan nilai rating. Peluang paling besar akan diberikan rating paling tinggi, begitu pula sebaliknya; 4) Menghitung skor terbobot pada setiap faktor dengan cara mengalikan bobot dengan rating.; 5) Interpretasi jumlah skor terbobot. Apabila jumlah skor lebih dari atau sama dengan 2,5 memiliki arti External system dapat merespon kondisi eksternal.

Hasil dari EFAS (External Factors Analysis Strategic) dapat dilihat dari Tabel 13 di bawah ini.

Tabel 13. Matriks Evaluasi Faktor EFAS

\begin{tabular}{|c|c|c|c|}
\hline $\begin{array}{l}\text { Faktor-faktor internal } \\
\text { kunci }\end{array}$ & Rating & Bobot & $\begin{array}{c}\text { Nilai } \\
\text { terbobot }\end{array}$ \\
\hline \multicolumn{4}{|l|}{ Peluang: } \\
\hline $\begin{array}{l}\text { Memiliki pelanggan } \\
\text { tetap }\end{array}$ & 3,2 & 0,13 & 0,43 \\
\hline $\begin{array}{l}\text { Kondisi alam yang } \\
\text { menjadi daya tarik } \\
\text { para tamu untuk } \\
\text { berkunjung ke Batu }\end{array}$ & 3,0 & 0,13 & 0,38 \\
\hline $\begin{array}{l}\text { Adanya permintaan } \\
\text { terhadap produk- } \\
\text { produk restoran hotel } \\
\text { dari orang luar yang } \\
\text { bukan tamu. }\end{array}$ & 3,4 & 0,14 & 0,48 \\
\hline $\begin{array}{l}\text { Dibukanya kembali } \\
\text { berbagai lokasi } \\
\text { wisata } \\
\text { memungkinkan } \\
\text { pelanggan untuk } \\
\text { datang berkunjung }\end{array}$ & \multicolumn{2}{|c|}{$\begin{array}{l}\text { memungkinkan } \\
\text { pelanggan untuk } \\
\text { datang berkunjung }\end{array}$} & 0,43 \\
\hline \multicolumn{4}{|l|}{$\begin{array}{l}\text { mulai jenuh di rumah } \\
\text { dan ingin berwisata } \\
\text { sehingga } \\
\text { membutuhkan iasa }\end{array}$} \\
\hline perhotelan. & & & 2,20 \\
\hline
\end{tabular}

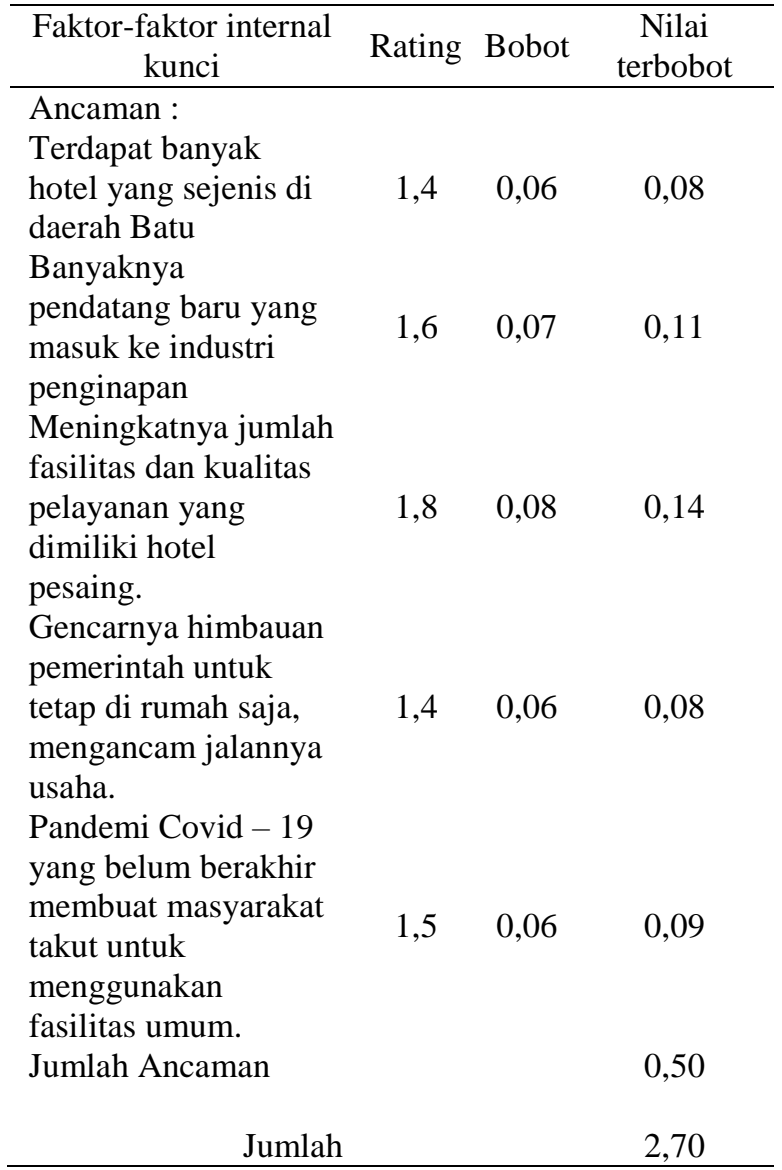

Sumber: Data primer diolah, 2021

Matriks SWOT didapatkan dari hasil analisis aspek internal, eksternal, dan juga melihat hasil dari IFAS dan EFAS sehingga strategi yang dapat dilaksanakan adalah sebagai berikut:

Tabel 14. Tabel Matriks SWOT

\begin{tabular}{cc} 
Strength $(\mathrm{S})$ & Weakness $(\mathrm{W})$ \\
\hline 1. Harga kamar & 1. Pelaksanaan \\
hotel yang & promosi \\
kompetitif & Hotel yang \\
2. Adanya & belum \\
tempat & efektif \\
bermain & 2. Jumlah \\
untuk anak & kamar yang \\
yang unik \& & sedikit \\
edukatif. & 3. Kondisi \\
3. Agrokusuma & hotel, \\
Hotel & terkadang \\
memiliki & ada keluhan \\
citra yang & 4. Tidak ada \\
baik & paket diskon \\
4. Memiliki & dalam \\
lokasi yang & pembelian \\
strategis & produk \\
untuk & pelayanan \\
& Hotel
\end{tabular}




\begin{tabular}{|c|c|c|}
\hline & $\begin{array}{l}\text { menarik } \\
\text { pelanggan. } \\
\text { 5. Keramahan } \\
\text { dan } \\
\text { kesopanan } \\
\text { pelayan } \\
\text { sangat } \\
\text { diperlukan } \\
\text { untuk } \\
\text { menarik } \\
\text { pelanggan. }\end{array}$ & $\begin{array}{l}\text { 5. Kurang } \\
\text { menerapkan } \\
\text { kemajuan } \\
\text { teknologi } \\
\text { dalam } \\
\text { memasarkan } \\
\text { produk }\end{array}$ \\
\hline Opportunity & Strategi SO & Strategi WO \\
\hline $\begin{array}{l}\text { 1. Memiliki } \\
\text { pelanggan } \\
\text { tetap } \\
\text { 2. Kondisi } \\
\text { alam yang } \\
\text { menjadi } \\
\text { daya tarik } \\
\text { para tamu } \\
\text { 3. Adanya } \\
\text { permintaan } \\
\text { terhadap } \\
\text { produk } \\
\text { 4. Dibukanya } \\
\text { kembali } \\
\text { berbagai } \\
\text { lokasi } \\
\text { wisata } \\
\text { 5. Masyarakat } \\
\text { yang mulai } \\
\text { jenuh di } \\
\text { rumah }\end{array}$ & $\begin{array}{l}\text { 1. Menjaga } \\
\text { harga kamar } \\
\text { hotel tetap } \\
\text { kompetitif } \\
\text { 2. Menyediakan } \\
\text { tempat } \\
\text { bermain } \\
\text { untuk anak- } \\
\text { anak } \\
\text { 3. Menjaga } \\
\text { citra tetap } \\
\text { baik } \\
\text { 4. selalu berada } \\
\text { pada lokasi } \\
\text { yang } \\
\text { strategis } \\
\text { 5. Menjaga } \\
\text { keramahan } \\
\text { dan } \\
\text { kesopanan } \\
\text { pelayan } \\
\text { 6. Diusahakan } \\
\text { memiliki } \\
\text { pelanggan } \\
\text { tetap } \\
\text { 7. Menjaga } \\
\text { kondisi alam } \\
\text { sekitar } \\
\text { 8. Selalu } \\
\text { menjaga } \\
\text { terpenuhinya } \\
\text { permintaan } \\
\text { 9. Dibuka } \\
\text { kembali } \\
\text { berbagai } \\
\text { lokasi wisata } \\
\text { 10.Mengatur } \\
\text { strategi } \\
\text { untuk } \\
\text { menghilangk } \\
\text { an kejenuhan } \\
\text { pelanggan }\end{array}$ & $\begin{array}{l}\text { 1.Mengefektifk } \\
\text { an } \\
\text { Pelaksanaan } \\
\text { promosi } \\
\text { 2. Menambah } \\
\text { jumlah } \\
\text { kamar } \\
\text { 3. Meningkatka } \\
\text { n kondisi } \\
\text { hotel } \\
\text { 4. Pemberian } \\
\text { paket diskon } \\
\text { 5. Pemanfaatan } \\
\text { dan } \\
\text { penerapkan } \\
\text { kemajuan } \\
\text { teknologi } \\
\text { 6. Diusahakan } \\
\text { memiliki } \\
\text { pelanggan } \\
\text { tetap } \\
\text { 7. Menjaga } \\
\text { kondisi } \\
\text { alam sekitar } \\
\text { 8. Selalu } \\
\text { menjaga } \\
\text { terpenuhiny } \\
\text { a } \\
\text { permintaan } \\
\text { 9. Dibuka } \\
\text { kembali } \\
\text { berbagai } \\
\text { lokasi } \\
\text { wisata } \\
\text { 10. Mengtur } \\
\text { strategi untuk } \\
\text { menghilangka } \\
\text { n kejenuhan } \\
\text { pelanggan }\end{array}$ \\
\hline Threats (T) & Strategi ST & Strategi WT \\
\hline $\begin{array}{l}\text { 1.Terdapat } \\
\text { banyak } \\
\text { hotel yang } \\
\text { sejenis }\end{array}$ & $\begin{array}{l}\text { 1. Menjaga } \\
\text { harga kamar } \\
\text { hotel tetap } \\
\text { kompetitif }\end{array}$ & $\begin{array}{l}\text { 1.Mengefektifk } \\
\text { an } \\
\text { Pelaksanaan } \\
\text { promosi }\end{array}$ \\
\hline
\end{tabular}

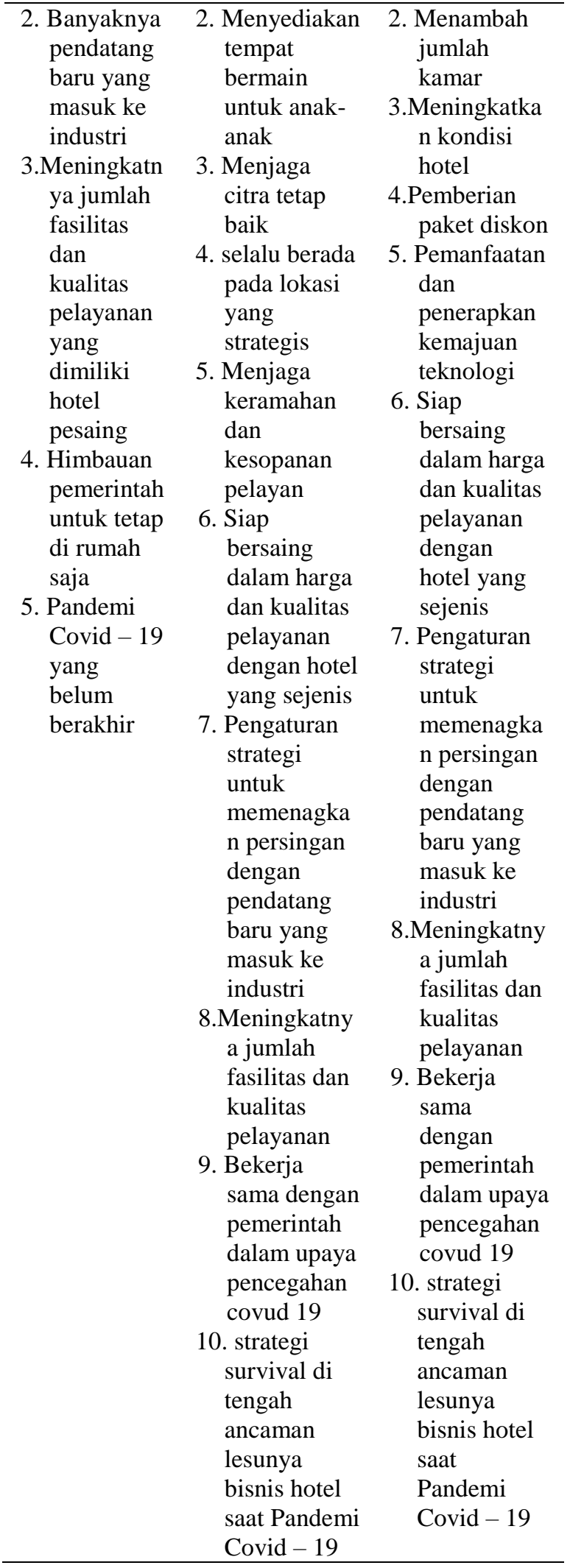

Sumber: Data primer diolah, 2021

Berdasarkan Tabel 14 diatas dapat diketahui bahwa faktor kekuatan memiliki nilai 1,58 kelemahan memiliki nilai 1,31, 
daktor peluang bernilai 2,20, dan faktor ancaman bernilai 0,50.

Maka diketahui nilai kekuatan diatas kelemahan selisih (+) 0,27 dan nilai peluang diatas nilai ancaman selisih (+) 1,70. Dari hasil identifikasi maka dapat digambarkan dalam diagram SWOT pada Gambar 2 di bawah ini.

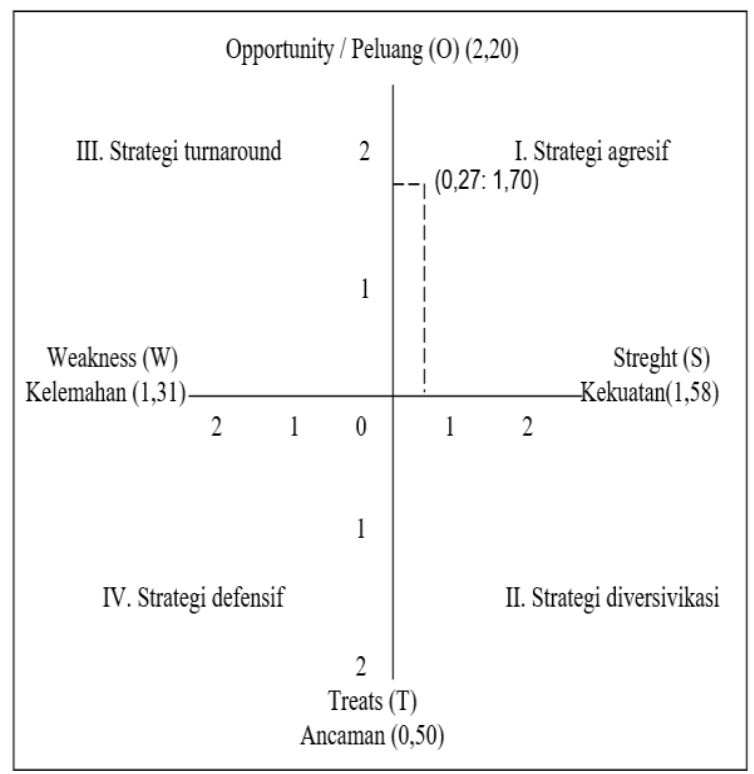

Gambar 2. Diagram Matrik SWOT

Sumber: Rangkuti,2006 \& Data primer diolah, 2021

Berdasarkan Diagram Matrik SWOT, didapatkan posisi pada kuadran I yang berarti pada posisi agresif. Ini merupakan situasi yang sangat menguntungkan. Hotel memiliki banyak peluang dan kekuatan sehingga bisa memanfaatkannya dengan baik. Strategi yang sebaiknya diterapkan dalam kondisi ini adalah mendukung kebijakan pertumbuhan yang agresif (growth oriented strategy). Salah satu contoh yang perlu dikembangkan adalah strategi differensiasi (Rangkuti, 2006), yang terdapat dalam indikator faktor internal yaitu adanya penyediaan tempat bermain anak yang unik dan edukatif.

\section{Kesimpulan Pemberian Skor}

Berdasarkan tabel matriks IFAS

(Internal Factors Analysis Strategic) menghasilkan nilai 2,89. Total skor 2,89 menunjukkan bahwa usaha hotel Kusuma Agrowisata Batu $\geq 2,5$ berarti kondisi internal sistem memiliki kekuatan untuk mengatasi situasi dalam usaha memanfaatkan kekuatannya dan menyembunyikan kelemahannya jika perlu.

Berdasarkan tabel EFAS (External Factors Analysis Strategic) Usaha hotel Kusuma Agrowisata menghasilkan nilai 2,60. Nilai tersebut menjelaskan Usaha hotel mampu memanfaatkan peluang-peluang yang ada pada bisnis yang mereka jalani dan dapat mengurangi ancaman yang timbul.

\section{Interpretasi Kinerja Balanced Scorecard}

Kinerja perspektif keuangan hotel Kusuma Agrowisata pada tahun 2019 berada pada kategori sangat baik tetapi pada tahun 2020 memperlihatkan bahwa perusahaan perlu meningkatkan pertumbuhan pendapatan (profitabilitas) dan efisiensi perusahaan serta melakukan inovasi selama masa pandemi Covid-19.

Kinerja perspektif pelanggan Hotel Kusuma Agrowisata berada pada kategori puas, ini menunjukkan bahwa perusahaan berhasil mempertahankan pemberian rasa puas pada pelanggan.

Kinerja perspektif proses bisnis internal Hotel Kusuma Agrowisata menunjukkan perusahaan mampu mencapai indeks efisiensi strategi perusahaan dari standar yang telah ditetapkan, hal ini ditunjukkan banyaknya respon positif karyawan terhadap strategi perusahaan yang meliputi pelayanan yang diberikan oleh hotel, kemudahan mengakses jasa yang ditawarkan oleh hotel, penyediaan fasilitas hotel secara umum, penyediaan layanan untuk kemudahan pemesanan (reservasi), serta respon hotel atas keluhan dan ketidakpuasan tamu.

Kinerja perspektif pembelajaran dan pertumbuhan menunjukkan produktifitas karyawan pada tahun 2019 mampu mencapai standart minimal, sedangkan pada tahun 2020 mengalami penurunan karena adanya pandemi covid 19. Tetapi secara umum hotel Kusuma Agrowisata mampu mencapai indeks kepuasan karyawan dari standar yang telah ditetapkan. 
Penentuan Strategi Bersaing Berdasarkan Analisis SWOT

Posisi Usaha Hotel Kusuma Agrowisata berada pada kuadran I yang berarti pada posisi agresif. Ini merupakan situasi yang sangat menguntungkan. Usaha hotel Kusuma Agrowisata memiliki peluang dan kekuatan sehingga dapat memanfaatkan peluang yang ada secara maksimal.

Strategi yang tepat pada posisi ini adalah strategi yang mendukung kebijakan pertumbuhan yang agresif yaitu strategi pertumbuhan (Growth Oriented Strategy). Berdasarkan kuadran posisi I maka, alternatif strategi yang sesuai dengan pada tabel SWOT adalah strategi SO (Strength Oppourtunities). strategi SO (Strength Oppourtunities) dilakukan dengan menciptakan strategi yang menggunakan kekuatan untuk memanfaatkan peluang.

Strategi SO memanfaatkan kekuatan internal Usaha Hotel Kusuma Agrowisata untuk menarik keuntungan dari peluang eksternal. Semua manajer menginginkan organisasi yang mereka pimpin berada dalam posisi di mana kekuatan internal dapat digunakan untuk mengambil keuntungan dari berbagai trend dan kejadian eksternal. Jika Usaha hotel Kusuma Agrowisata memiliki kelemahan besar, maka perusahaan akan berjuang untuk mengatasinya dan mengubahnya menjadi kekuatan. Ketika organisasi di hadapkan pada ancaman yang besar, maka Usaha Hotel Kusuma Agrowisata akan berusaha menghindarinya untuk berkonsentrasi pada peluang.

Strategi SO (Strength Oppourtunities) yaitu dengan memanfaatkan kekuatan yang dimiliki perusahaan untuk meraih peluang yang ada. Pada aplikasinya Strategi S-O (Strength- Oppourtunities) sesuai dengan hasil penelitian, sebagai berikut: 1) Menjaga harga kamar hotel agar bisa tetap kompetitif, 2) Menyediakan tempat bermain untuk anak yang unik dan edukatif, 3) Menjaga citra hotel tetap baik, 4) Selalu berada pada lokasi yang strategis, 5) Menjaga keramahan dan kesopanan pelayan 6) Diusahakan memiliki pelanggan tetap, 7) Menjaga kondisi alam sekitar, 8) Selalu menjaga terpenuhinya permintaan tamu, 9) Dibuka kembali berbagai lokasi wisata disekitar area hotel, 10) Mengatur strategi untuk menghilangkan kejenuhan pelanggan.

Penelitian mengenai pengukuran kinerja perusahaan menggunakan Metode balanced scorecard juga telah dilakukan oleh Panudju et al. (2016) di PT ABC, Tbk. Panuju menemukan bahwa Perspektif bisnis internal adalah perspektif terpenting dibandingkan dengan perspektif lainnya dengan bobot 0,350 . Dengan hasil tersebut, perusahaan dapat lebih memfokuskan pada meningkatkan bisnis internal, meningkatkan kualitas produk dan efektivitas operasi dalam menghasilkan produk serta pengembangan jaringan rantai pasok.

\section{Kesimpulan}

Kinerja Hotel Kusuma Agrowisata dinilai dengan Balance Scorecard, sebagai berikut: 1) Perspektif keuangan: berdasarkan hasil perhitungan kinerja perspektif keuangan Kusuma Agrowisata pada tahun 2019 memperlihatkan kinerja sangat baik, akan tetapi pada tahun 2020 mengalami penurunan pendapatan yang cukup signifikan yang disebabkan oleh kondisi pandemi Covid-19. Hal ini berdampak pada posisi keuangan perusahaan yang menurun, maka dapat disimpulkan Hotel Kusuma Agrowisata perlu meningkatkan pertumbuhan pendapatan (profitabilitas) dan efisiensi perusahaan serta melakukan berbagai inovasi produk dan jasa; 2) Perspektif pelanggan: pelanggan Hotel Kusuma Agrowisata dikategorikan puas. Indeks kepuasan pelanggan yang diperoleh dari penyebaran kuesioner pada kategori puas. Hal ini berarti Hotel Kusuma Agrowisata mampu mencapai indeks kepuasan pelanggan dari standar yang telah ditetapkan. Berdasarkan hasil perhitungan kinerja perspektif pelanggan memperlihatkan bahwa kondisi tersebut menunjukkan berhasil mempertahankan pemberian rasa puas pada pelanggan; 3) Perspektif proses bisnis internal: indeks efisiensi yang diperoleh berada pada kategori efisien. Dari perhitungan tersebut berarti strategi perusahaan termasuk pada kategori efisien. 
Hal ini berarti Hotel Kusuma Agrowisata mampu mencapai indeks efisiensi strategi perusahaan dari standar yang telah ditetapkan; 4) Perspektif pembelajaran dan pertumbuhan: indeks kepuasan karyawan yang diperoleh berada pada kategori puas. Berarti karyawan termasuk pada kategori puas. Hal ini berarti hotel Kusuma Agrowisata mampu mencapai indeks kepuasan karyawan dari standar yang telah ditetapkan yaitu minimal karyawan merasa puas.

Rancangan strategi bisnis Hotel Kusuma Agrowisata dengan analisis SWOT. Dari perhitungan analisa SWOT ditemukan Strategi SO (Strength Opportunities) yaitu dengan memanfaatkan kekuatan yang dimiliki perusahaan untuk meraih peluang yang ada. Pada aplikasinya Strategi SO (Strength Opportunities) sesuai dengan hasil penelitian menunjukkan bahwa : 1) Menjaga harga kamar hotel agar bias tetap kompetitif; 2) Menyediakan tempat bermain untuk anak yang unik dan edukatif; 3) Menjaga citra hotel tetap baik; 4) Selalu berada pada lokasi strategis; 5) Selalu menjaga keramahan dan kesopanan pelayan; 6) Diusahakan memiliki pelanggan tetap; 7) Menjaga kondisi alam sekitar; 8) Selalu menjaga terpenuhinya permintaan tamu; 9) Dibukanya kembali berbagai lokasi wisata di area sekitar hotel; 10) Mengatur strategi untuk menghilangkan kejenuhan pelanggan.

Dari hasil penelitian diatas, beberapa saran yang dapat disampaikan kepada perusahaan: 1) Perusahaan harus selalu meningkatkan pertumbuhan pendapatan (profitabilitas) dan efisiensi perusahaan serta inovasi seperti: menjadi penyelenggara acara keluarga (acara kecil) yang sifatnya terbatas; 2) Mempertahankan pemberian rasa puas pada pelanggan dibuktikan dengan ulasan pelanggan pada aplikasi hotel sebagai umpan balik; 3) Ikut mempromosikan lokasi tempat wisata di area sekitar hotel, 4) Remarketing atau pemasaran ulang produk atau jasa pada aplikasi hotel dengan membuat iklan khusus yang ditujukan kepada user yang sebelumnya pernah melakukan interaksi dengan situs web hotel, 5) Departemen Food \& Beverage Hotel Kusuma Agrowisata menjalin kerjasama dengan Gojek atau Grab yang menyediakan layanan penjualan makanan secara online dan memproduksi frozen food (makanan beku) siap saji sebagai usaha untuk menambah pendapatan.

\section{DAFTAR PUSTAKA}

Benková, E., Gallo, P., Balogová, B., \& Nemec, J. (2020). Factors affecting the use of balanced scorecard in measuring company performance. Sustainability, 12(3), 1178.

Chih-Pei, H. U., \& Chang, Y.-Y. (2017). John W. Creswell, Research design: Qualitative, quantitative, and mixed methods approaches. Journal of Social and Administrative Sciences, 4(2), 205207.

Detik Finance. (2020). Meneropong Nasib Bisnis Hotel di Tengah Pandemi. https://finance.detik.com/properti/d5085126/meneropong-nasib-bisnishotel-di-tengah-pandemi

Diana Riyana, H. (2017). Pengukuran Kinerja Perusahaan PT Indofood dengan Menggunakan Balanced Scorecard. Jurnal SEKURITAS (Saham, Ekonomi, Keuangan Dan Investasi), 1(2): 42-53

Jpnn.com. (2020). Ternyata dari Lokasi ini, Awal Covid-19 di Kota Batu. https://www.jpnn.com/news/ternyatadari-lokasi-ini-awal-covid-19-di-kotabatu

Kaplan R.S., Norton D.P. (2007) Balanced Scorecard. In: Boersch C., Elschen R. (eds) Das Summa Summarum des Management. Gabler. https://doi.org/10.1007/978-3-83499320-5_12

Kurniasari, V. (2017). Analisis Kinerja Perusahaan Menggunakan Metode Balanced Scorecard (Studi Kasus Pada PT. Aditya Sentana Agro). Agora, 5(1).

Panudju, A. T., Asfar, A. H., \& Fauziah, F. (2016). Pengukuran Kinrja Perusahaan Menggunakan Metode Balanced Scorecard (BSC) dengan Pembobotan Analytical Hierarchy Process (AHP) Di PT. ABC, TBK. Integrasi Sistem Industri, 3(2), 55-65. 
https://dx.doi.org/10.24853/jisi.4.1.pp$\mathrm{pp}$

Permatasari, D. E. (2015). Penentuan Strategi

Bisnis Manajemen Hotel dalam Menghadapi Persaingan (Studi Kasus Di Quds Royal Hotel Surabaya). Jurnal Administrasi Bisnis, 27(1): 1-8

Melasari, Santi., Sujana, I Nyoman., Suwena, Kadek Rai. (2018). Analisis SWOT pada Hotel Banyualit Singaraja. Jurnal Pendidikan Ekonomi Undiksha. 10(2):365-375

Porter, M. E. (1980). Competitive strategy: Techniques for analyzing industries and competitors. New York: The Free Press.

Rangkuti, F. (2006). Analisis SWOT: Teknik Membedah Kasus Bisnis. Jakarta: PT. Gramedia Pustaka Utama.

Sumarsono, D. (2014). Winning Competition. Jakarta: Gramedia.

Widiasri, K. S., Atmadja, A. T., SE, A., Herawati, N. T., \& Ak, S. E. (2017). Pengukuran Kinerja dengan Metode
Balanced Scorecard Pada PT. Bank Pembangunan Daerah Bali Cabang Singaraja Tahun 2014. Jimat (Jurnal Ilmiah Mahasiswa Akuntansi) Undiksha, 6(3).

Widyastuti, I. T., Indriana, I., Umar, A., \& Bawono, A. (2018). Analisis Kinerja Perusahaan Dengan Metode Balanced Scorecard (Studi Kasus Pt Xyz Bergerak Di Bidang Telekomunikasi). Jurnal Administrasi dan Kesekretarisan, 2(2), 124-137. 